\title{
Evaluation of quality protein maize as a feed ingredient for layer pullet
}

\author{
S.A Osei, H.K Dei and A.K. Tuah
}

Department of Animal Science, University of Science and Technology

Kumasi, Ghana

(Received 10 July 1998; accepted 19 March 1999)

\begin{abstract}
The experiment was carried out in two periods, growing and laying, on 300 eight-week-old pullets (Shaver Starcross 579 strain). In the growing period (8-18 weeks of age) five iso-caloric diets were used: controls containing normal maize and fish meal, with $16 \% \mathrm{CP}$ (NM1) or 14\% CP (NM2); three experimental in which normal maize was replaced by quality protein maize, with 16,15 or $14 \% \mathrm{CP}$, QPM1, QPM2 or QPM3, respectively. In the laying period similar diets were used, but with lower CP contents: $15,13,15,14$ and $13 \%$, respectively.

The replacement of NM by QPM in the diet with $14 \% \mathrm{CP}$ (QPM3) did not significantly reduce the performance of growing birds in comparison with birds fed the NM1 diet with $17 \%$ CP. The NM2 diet significantly $(P<0.05)$ depressed growth and feed efficiency. In the laying period, QPM3 and NM2 diets $(13 \% \mathrm{CP})$ depressed the pullets' performance. The obtained results indicate that the level of CP in the layer diets may be reduced to $14 \%$ when NM is replaced by QPM.
\end{abstract}

KEY WORDS: protein, maize, layer chicken

\section{INTRODUCTION}

Normal maize supplies up to a third or more of the crude protein content of chicken diets (Schaible, 1970). On the other hand, maize is low in protein in addition to its general deficiency in essential amino acids, particularly lysine and tryptophan (NRC, 1988). Thus, the feeding normal maize necessitates the use of expensive protein supplements, including fish meal and soyabean meal. Quality protein maize, a derivative of opaque- 2 maize, was originally developed at the International Maize and Wheat Improvement Center (CIMMYT) in Mexico. Nutritional evaluation of 
quality protein maize (QPM) in various locations has proved the superiority of QPM over normal maize in the feeding of rats (Sproule et al., 1988), pigs (Knabe et al., 1992; Okai et al., 1994), broiler and layer chickens (Bond et al., 1991; Liu et al., 1993).

Quality protein maize was released in Ghana in the early 1990s by the Crops Research Institute, Kumasi. However, it has not been critically evaluated as a feed ingredient for layers. Osei et al. (1994) have shown, however, that QPM is superior to normal maize when used either as the sole source of protein and amino acids or in balanced diets for broiler chickens.

This trial was undertaken to study the feeding value of QPM in comparison with normal maize in diets for grower and layer chickens.

\section{MATERIAL AND METHODS}

The normal and quality protein maize used in the trials were purchased from certified seed growers from various locations in Ghana. They were chemically analyzed for their approximate and amino acid compositions by conventional methods (AOAC, 1984).

The trial was conducted in two phases: a grower phase from 8 to 18 weeks and a layer phase from week 19 to week 51 . In the grower trial, three hundred 8-weekold Shaver Starcross 579 chickens obtained from Pomadze Poultry Enterprises Ltd., Winneba, Ghana, were randomly divided into five dietary treatments in equal numbers as shown in Table 1. Each treatment had four replicates. The control diet, NM1 was composed largely of normal maize (NM) and fish meal to provide a crude protein content of $16 \%$ (NRC, 1994). Three other diets were formulated in which QPM replaced normal maize, denoted as QPM1, QPM2 and QPM3 and containing respectively 16,15 and $14 \%$ crude protein. The fifth diet also contained normal maize (NM2), with a protein level of $14 \%$. For the layer trial, all the birds from the grower phase were combined together at the end of the 18th week and then subsequently randomly re-allocated in equal numbers among five layer dietary treatments as shown in Table 2.

During both phases, an increase in the use of QPM was coupled with a reduction in the incorporation of fish meal. The diets were formulated to be largely isocaloric with only slight differences in metabolizable energy contents (Tables 1 and 2). The birds were housed in raised wire-floor coops providing a floor space per bird of approximately $0.14 \mathrm{~m}^{2}$. Feed and water were provided ad libitum throughout the trials.

Data were collected for feed intake, body weight changes, feed conversion ratio, egg production, egg weight, internal egg quality or Haugh unit, egg shell thickness, and mortality. In addition, the economics of production were calculated for each treatment. All data were subjected to analysis of variance while significant 
TABLE 1

Composition and nutrient analysis of grower experimental diets

\begin{tabular}{lccccc}
\hline \multirow{2}{*}{ Ingredients, $\mathrm{g} \mathrm{kg}^{-1}$} & \multicolumn{5}{c}{ Experimental diets } \\
\cline { 2 - 6 } & NM1 & QPM1 & QPM2 & QPM3 & NM2 \\
\hline Normal maize & 574 & - & - & - & 600 \\
QPM & - & 570 & 585 & 600 & - \\
Fish meal, 65\% CP & 60 & 60 & 35 & 20 & 20 \\
Wheat bran & 320 & 328 & 330 & 334 & 330 \\
Cottonseed cake & 26 & 22 & 30 & 26 & 30 \\
Dicalcium phosphate & 10 & 10 & 10 & 10 & 10 \\
Oyster shell & 5 & 5 & 5 & 5 & 5 \\
Premix & 2.5 & 2.5 & 2.5 & 2.5 & 2.5 \\
Common salt & 2.5 & 2.5 & 2.5 & 2.5 & 2.5
\end{tabular}

Analysed composition ( $\left.\mathrm{g} \mathrm{kg}^{-1}\right)$, except gross/ metabolizable energy $\left(\mathrm{MJ} \mathrm{kg}^{-1}\right)$

\begin{tabular}{lrrrrr} 
Crude protein & 161.5 & 161.8 & 153.3 & 142.5 & 144.3 \\
arginine & 9.0 & 8.9 & 10.2 & 9.0 & 7.5 \\
glycine & 8.2 & 8.1 & 7.8 & 6.8 & 5.8 \\
isoleucine & 6.1 & 5.6 & 7.6 & 6.5 & 4.7 \\
leucine & 14.8 & 11.9 & 11.9 & 10.7 & 13.0 \\
lysine & 6.8 & 7.0 & 7.2 & 5.8 & 4.5 \\
methionine & 3.4 & 3.2 & 3.2 & 2.7 & 2.6 \\
cystine & 3.2 & 3.1 & 3.1 & 2.9 & 2.8 \\
phenylalanine & 7.5 & 6.5 & 6.9 & 6.0 & 6.5 \\
threonine & 5.2 & 4.9 & 5.2 & 4.6 & 4.6 \\
tryptophan & 1.6 & 1.5 & 1.8 & 1.6 & 1.6 \\
valine & 7.9 & 7.7 & 8.0 & 7.0 & 6.2 \\
& & & & & \\
Gross energy & 13.53 & 13.53 & 13.66 & 13.69 & 13.82 \\
Metabolizable energy ${ }^{2}$ & 11.50 & 11.50 & 11.60 & 11.60 & 11.70 \\
Moisture & 116.3 & 116.5 & 111.6 & 116.8 & 110.4 \\
Ether extract & 4.7 & 5.1 & 6.3 & 7.2 & 6.2 \\
Crude fibre & 32.7 & 36.7 & 36.3 & 33.8 & 34.8 \\
Ash & 52.2 & 48.4 & 47.4 & 43.2 & 40.0 \\
Nitrogen-free extractives & 748.9 & 748.0 & 756.7 & 773.3 & 774.7 \\
\hline
\end{tabular}

1 vitamin-mineral premix provided per kg diet: vitamins A, 2million IU; D, 400,000 IU; E, 3,000 IU; $\mathrm{K}, 200 \mathrm{IU} ; \mathrm{B}_{1}, 200 \mathrm{mg} ; \mathrm{B}_{2}, 900 \mathrm{mg} ; \mathrm{B}_{12}, 2,400 \mathrm{mg}$; niacin, 5,000 mg; and minerals Fe, $9,000 \mathrm{mg}$; $\mathrm{Cu}$, $500 \mathrm{mg}$; Mn, 12,000 mg; Co, $100 \mathrm{mg} ; \mathrm{Zn}, 10,000 \mathrm{mg} ; \mathrm{I}, 400 \mathrm{mg}$; and Se, 4

${ }^{2}$ metabolizable energy values calculated; gross energy values analysed 
TABLE 2

Dietary and nutrient composition of layer rations

\begin{tabular}{lccccc}
\hline \multirow{2}{*}{ Ingredients, $\mathrm{gkg}^{-1}$} & \multicolumn{5}{c}{ Experimental diets } \\
\cline { 2 - 6 } & NM1 & QPM1 & QPM2 & QPM3 & NM2 \\
\hline Normal maize & 565.0 & - & - & - & 595.0 \\
QPM & - & 560 & 585 & 595 & - \\
Fish meal & 85 & 80 & 65 & 45 & 48 \\
Wheat bran & 260 & 270 & 260 & 270 & 267 \\
Dicalcium phosphate & 10 & 10 & 10 & 10 & 10 \\
Oyster shell & 75 & 75 & 75 & 75 & 75 \\
Premix & 2.5 & 2.5 & 2.5 & 2.5 & 2.5 \\
Common salt & 2.5 & 2.5 & 2.5 & 2.5 & 2.5
\end{tabular}

Analysed composition ( $\mathrm{g} \mathrm{kg}^{-1}$ ), except gross/metabolizable energy ( $\mathrm{MJ} \mathrm{kg}^{-1}$ )

\begin{tabular}{|c|c|c|c|c|c|}
\hline Crude protein & 150.4 & 152.8 & 143.3 & 130.5 & 130.3 \\
\hline arginine & 8.1 & 9.1 & 8.1 & 7.0 & 6.5 \\
\hline glycine & 7.8 & 8.2 & 7.7 & 6.3 & 6.4 \\
\hline isoleucine & 5.9 & 5.9 & 5.6 & 4.5 & 4.9 \\
\hline leucine & 13.5 & 12.8 & 12.4 & 10.1 & 12.5 \\
\hline lysine & 7.6 & 8.4 & 7.3 & 5.8 & 5.4 \\
\hline methionine & 3.5 & 3.6 & 3.3 & 2.6 & 3.0 \\
\hline cystine & 2.7 & 2.8 & 2.9 & 2.5 & 2.5 \\
\hline phenylalanine & 6.6 & 6.6 & 6.3 & 5.2 & 5.8 \\
\hline threonine & 5.1 & 5.7 & 5.2 & 4.3 & 4.8 \\
\hline tryptophan & 1.2 & 1.6 & 1.5 & 1.4 & 1.3 \\
\hline valine & 7.6 & 7.8 & 7.4 & 6.5 & 6.5 \\
\hline Metabolizable energy $^{2}$ & 10.90 & 10.80 & 10.80 & 10.85 & 10.75 \\
\hline Moisture & 107.3 & 109.9 & 110.4 & 102.6 & 103.6 \\
\hline Crude fibre & 34.3 & 24.4 & 28.2 & 21.8 & 27.0 \\
\hline Ether extract & 5.0 & 6.6 & 5.0 & 6.8 & 4.6 \\
\hline Ash & 98.7 & 118.3 & 112.3 & 124.7 & 126.7 \\
\hline $\mathrm{Ca}$ & 35.0 & 35.0 & 34.0 & 33.5 & 33.7 \\
\hline$P$, available & 4.1 & 3.9 & 3.4 & 3.1 & 3.3 \\
\hline Gross energy (analysed) & 12.86 & 12.69 & 12.69 & 12.77 & 12.60 \\
\hline Nitrogen-free extractives & 711.6 & 697.9 & 711.2 & 716.2 & 711.4 \\
\hline
\end{tabular}

premix as in Table 1

${ }^{2}$ metabolizable energy values calculated 
differences among means were isolated by means of Fisher's least squares differences test (Steel and Torrie, 1980).

\section{RESULTS AND DISCUSSION}

The approximate and essential amino acid compositions of QPM and normal maize are presented in Table 3. The approximate composition of QPM was similar to that of normal maize, although QPM tended to have higher levels of crude protein, ether extract, crude fibre and gross energy. Similar observations have been made by Burgoon et al. (1992), Ahenkora et al. (1994) and Martinez et al. (1996). The amino acid profiles show that of the five critical amino acids, QPM had higher levels of arginine $(+25 \%)$, cystine $(+35 \%)$, tryptophan $(+33 \%)$ and lysine $(+33 \%)$ than normal maize, while the level of methionine in QPM was $5 \%$ less than in normal maize. In addition, the ratio of leucine to isoleucine was lower in QPM than in normal maize (3.0:1 vs 3.47:1 respectively). Earlier studies have provided similar data (Burgoon et al., 1992; Zarkadas et al., 1995).

Data on the performance of growing pullets is summarized in Table 4. The initial body weights did not differ among the treatments. However, birds receiving the

TABLE 3

Proximate and amino acid composition' of QPM and normal maize ( $\mathrm{g} \mathrm{kg}^{-1} \mathrm{DM}$, except GE)

\begin{tabular}{lccc}
\hline Dietary components & Quality protein maize & Normal maize & QPM: NM \\
\hline Moisture & 106.6 & 112.5 & 0.95 \\
Ether extract & 51.2 & 44.8 & 1.14 \\
Crude fibre & 21.4 & 19.3 & 1.11 \\
Ash & 16.0 & 19.0 & 0.84 \\
Nitrogen-free extractives & 713.7 & 715.2 & 1.00 \\
& & & \\
Crude protein & 91.1 & 89.2 & 1.02 \\
$\quad$ arginine & 5.0 & 4.0 & 1.25 \\
glycine & 4.2 & 3.4 & 1.23 \\
isoleucine & 3.1 & 3.4 & 0.91 \\
leucine & 9.3 & 11.8 & 0.79 \\
lysinc & 3.2 & 2.4 & 1.33 \\
methionine & 1.8 & 1.9 & 0.95 \\
cystine & 2.5 & 1.9 & 1.32 \\
phenylalanine & 3.9 & 4.6 & 0.85 \\
threonine & 3.1 & 2.9 & 1.07 \\
tryptophan & 0.8 & 0.6 & 1.33 \\
valine & 4.9 & 4.6 & 1.07 \\
Gross energy, $\mathrm{MJ} \mathrm{kg}^{-1}$ & 16.76 & 14.71 & 1.13 \\
\hline
\end{tabular}

' each value is the mean of duplicate determinations 
TABLE 4

Effects of diets on the performance of growing pullets

\begin{tabular}{lcccccc}
\hline & \multicolumn{5}{c}{ Experimental diets } & \multirow{2}{*}{ Overall } \\
\cline { 2 - 6 } Indices & $\mathrm{NM} 1$ & $\mathrm{QPM} 1$ & $\mathrm{QPM} 2$ & $\mathrm{QPM} 3$ & $\mathrm{NM} 2$ & $\mathrm{SE}^{\prime}$ \\
\hline Initial body weight, $\mathrm{g}$ & 575.8 & 575.8 & 575.8 & 575.8 & 575.8 & \\
Average daily gain, $\mathrm{g}$ & $12.5^{\mathrm{A}}$ & $13.1^{\mathrm{A}}$ & $12.5^{\mathrm{A}}$ & $12.3^{\mathrm{A}}$ & $11.0^{\mathrm{B}}$ & 0.35 \\
Final body weight, $\mathrm{g}$ & $1536.7^{\mathrm{A}}$ & $1583.3^{\mathrm{A}}$ & $1538.3^{\mathrm{A}}$ & $1521.7^{\wedge}$ & $1425.0^{\mathrm{B}}$ & 25.7 \\
Daily feed intake, $\mathrm{g} / \mathrm{bd}$ & 82.0 & 82.4 & 82.3 & 79.2 & 84.2 & 1.70 \\
Feed: gain ratio & $8.86^{\mathrm{A}}$ & $7.48^{\mathrm{A}}$ & $7.63^{\wedge}$ & $7.46^{\wedge}$ & $11.65^{\mathrm{B}}$ & 1.80 \\
Mortality & $0 / 60$ & $0 / 60$ & $0 / 60$ & $0 / 60$ & $0 / 60$ & - \\
\hline
\end{tabular}

$\mathrm{A}, \mathrm{B}-\mathrm{P}<0.01$

I $S E=$ standard error of mean

QPM1 diet with $16 \%$ crude protein grew faster and gained weight more rapidly than all the others although the differences were not significant when compared with counterparts on NM1, QPM2 and QPM3. Subsucan et al. (1990) and Liu et al. (1993) similarly found no significant differences in growth rates of birds fed either normal maize or QPM provided that they had comparable amino acid profiles. On the other hand, growth and gain were significantly depressed in birds fed on the second normal maize diet (NM2) containing $14 \%$ protein $(\mathrm{P}<0.01)$. The depressed growth of the low-protein normal maize birds (NM2) was probably due to the limiting levels of lysine (Harms and Waldroup, 1963). In this trial the lysine level in NM2 was only $0.45 \%$ of the diet compared to the NRC (1994) recommended value of $0.60 \%$.

There were no significant dietary treatment effects on average daily feed intake or on mortality $(\mathrm{P}>0.05)$. Birds on diet NM2 tended to consume more feed, however. On the other hand the efficiency of feed conversion was severely depressed when birds were fed the second NM diet with only $14 \%$ crude protein $(\mathrm{P}<0.01)$. Cromwell et al. (1967) and Chi and Speers (1973) similarly reported significantly depressed feed conversion efficiencies for chickens fed on normal maize compared with counterparts receiving opaque- 2 maize.

The results of the grower phase suggest that when QPM is added to pullet diets, the protein level can be reduced to $14 \%$ without any adverse effects on their performance. In comparison, when normal maize is used, performance is lowered. Sullivan et al. (1989) have attributed the superiority of quality protein maize to its higher content of lysine and tryptophan and its better amino acid balance.

The addition of QPM to layer diets had no significant effects on daily feed intake, feed-to-egg ratio, age at $5 \%$ hen-day production, egg weight, Haugh unit score, or shell thickness (Table 5). There were, however, significant differences in the ages at first egg $(\mathrm{P}<0.01), 50 \%$ production $(\mathrm{P}<0.05)$ and hen-day and hen- 
TABLE 5

Laying performance of birds as affected by normal maize and QPM

\begin{tabular}{lcccccc}
\hline Indices & NM1 & QPM l & QPM2 & QPM3 & NM2 & \pm SE \\
\hline Mean feed intake, g/d & 121.09 & 121.33 & 116.04 & 112.30 & 119.97 & 2.53 \\
Age at first egg, d & $123^{\mathrm{a}}$ & $-121^{\mathrm{a}}$ & $117^{\mathrm{b}}$ & $124^{\mathrm{a}}$ & $125^{\mathrm{a}}$ & $1.35^{* *}$ \\
Age at 5\% production, d & 128 & 127 & 124 & 134 & 130 & 2.08 \\
Age at 50\% production, d & $141^{\mathrm{a}}$ & $140^{\mathrm{a}}$ & $130^{\mathrm{b}}$ & $142^{\mathrm{a}}$ & $142^{\mathrm{a}}$ & $2.47^{*}$ \\
Hen-day production, \% & $77.4^{\mathrm{a}}$ & $77.3^{\mathrm{a}}$ & $72.0^{\mathrm{a}}$ & $64.3^{\mathrm{b}}$ & $66.8^{\mathrm{b}}$ & $1.49^{* * *}$ \\
Hen-housed production, \% & $75.2^{\mathrm{a}}$ & $77.3^{\mathrm{a}}$ & $72.0^{\mathrm{a}}$ & $62.3^{\mathrm{b}}$ & $63.7^{\mathrm{h}}$ & $1.91^{* * *}$ \\
Mean egg weight, g & 58.9 & 58.5 & 58.0 & 56.5 & 57.7 & 0.57 \\
Feed: egg (w/w) & 2.06 & 2.08 & 2.00 & 1.99 & 2.09 & 0.04 \\
Haugh unit score & 87.1 & 89.6 & 89.0 & 93.2 & 91.9 & 1.46 \\
Mean shell thickness, mm & 0.35 & 0.36 & 0.35 & 0.35 & 0.35 & 0.004 \\
Cost of grower feed, \$/tonne & 147.58 & 145.36 & 133.10 & 125.43 & 125.74 & - \\
Cost of layer feed, \$/tonne & 202.01 & 198.14 & 188.96 & 175.45 & 177.55 & - \\
Mortality & $2 / 60$ & $0 / 60$ & $0 / 60$ & $6 / 60$ & $7 / 60$ & - \\
\hline
\end{tabular}

1 means in a row with different letters are significantly different $*(\mathrm{P}<0.05), * *(\mathrm{P}<0.01)$ and $* * *(\mathrm{P}<0.001)$

housed production $(\mathrm{P}<0.001)$. In all cases, the diets with $13 \%$ crude protein (QPM3 and NM2) showed significantly poorer values although the differences between them were not significant. Similarly, the birds on QPM3 and NM2 tended to have increased mortality largely due to cannibalism. A look at the two diets indicates that with a reduction in fish meal incorporation to below $5 \%$ there were drastic reductions in essential amino acids relative to the other treatments, and deficiencies of arginine, leucine, isoleucine, lysine and methionine were evident (Table 2). There were, in addition, slight reductions in calcium and available phosphorus levels, but they all fell within the range of daily requirements and the calcium:phosphorus ratios were within the recommendations (NRC, 1994).

It was more economical to use diets incorporating quality protein maize (Table 5) due largely to the progressive reductions in the use of fish meal and the attendant savings in costs. Fish meal cost four times as much as maize per kilogram at the time of the experiment.

The results from these studies indicate that quality protein maize can be used in layer chicken diets to cut down on the use of fish meal and result in considerable financial benefits without sacrificing performance.

\section{ACKNOWLEDGMENTS}

The financial and material contributions of the Ghana Office of Sasakawa Global 2000 are duly acknowledged. 


\section{REFERENCES}

Ahenkora K., Twumasi-Afriyie S., Nagai D., Haag W., Asirifi-Yeboah K., Dzah B.D., 1994. QPM (Obatanpa) as a food source in Ghana: nutritional composition, rat growth and protein quality trials. Proc. Ghana Anim. Sci. Assoc. Symp. 22, 25-30

Association of Official Analytical Chemists, 1984. Official Methods of Analysis, 15th Edition. AOAC. Washington, DC

Bjarnason M., Vasal S.K., 1992. Breeding of quality protein maize (QPM). Plant Brecding Rev. 9, $181-216$

Boorman K.N., 1979. Dietary constraints on nitrogen retention. In: K.N. Boorman, B.M. Freeman (Editors). Food Intake Regulation in Poultry. British Poultry Science, Edinburgh

Burgoon K.G., Hansen J.A., Knabe D.A., Bockholt A.J., 1992. Nutritional value of quality protein maize for starter and grower swine. J. Anim. Sci. 70, 811-817

Card L.E., Nesheim M.C., 1972. Poultry Production. 11 th Edition. Lea and Febiger, Philadelphia

Chi M.S., Speers G.M., 1973. Nutritional value of high-lysine corn for the broiler chick. Poultry Sci. $52,1148-1157$

Cromwell G.L, Rogler J.C., Featherston W.R., Pickett R.A., 1967. Nutritional value of opaque-2 corn for the chick. Poultry Sci. 46, 704-712

Fisher H., Shapiro R., 1961. Protein reserves: interrelationship of dietary essential and non-essential amino acids. J. Nutr. $75,395-401$

Harms R.H., Waldroup P.W., 1963. Length of laying cycles as influenced by dietary protein level. Poultry Sci. 42, 1192-1197

Harper A.E., Benevega N.J., Wohlhueter R.M., 1970. Effects of the ingestion of disproportionate amounts of amino acids. Physiol. Rev. 50, 428-558

Knabe D.A., Sullivan J.S., Burgoon K.G., 1992. QPM as a swine feed. In: E.T. Mertz (Editor). Quality Protein Maize. The American Association of Cereal Chemists

Liu Z.X., Jie S.F., Guo X.F., Xu J.F., Wang L.M., 1993. Research in selected high quality protein maize hybrids. Maize Genet. Newslett. 67, 50-52

Martinez B.F., Sevilla P.E, Bjarnason M., 1996. Wet-milling comparison of quality protein maize and normal maize. J. Sci. Food Agric. 71, 156-162

Mertz E.T., Bates L.S., Nelson O.E., 1964. Mutant gene that changes protein composition and increases lysine content of maize endosperm. Science 145, 279-280

National Research Council, 1988. Quality Protein Maize. National Academy Press, Washington, DC

National Research Council, 1994. Nutrient Requirements of Poultry. 9th Revised Edition. National Academy Press, Washington, DC

Okai D.B., Osei S.A., Tuah A.K., Twumasi-Afriyie S., Haag W., Dzah B.D., Ahenkora K., Osafo E.L.K., 1994. The usefulness of Obatanpa, a quality protein maize in the feeding of pigs in Ghana. Proc. Ghana Anim. Sci. Symp. 22, 37-43

Ortega E., Bates L.S., 1983. Biochemical and agronomic studies of two modified hard-endosperm opaque-2 maize populations. Cereal Chem. 60,107-111

Osei S.A., Atuahene C.C., Donkoh A., Kwarteng K., Ahenkora K., Dzah B.D., Haag W., TwumasiAfriyie S., 1994. Further studies on the use of QPM as a feed ingredient for broiler chickens. Proc. Ghana Anim. Sci. Assoc. Symp. 22, 51-55

Schaible P.J, 1970. Poultry Feeds and Nutrition. Ist Edition. Avi Publishing Co., Westport, Connecticut Scott, M.L., Nesheim M.C., Young R.J., 1982. The Nutrition of the Chicken. 2nd Edition. M.L. Scott and Assoc., Ithaca, New York

Sproule A.M., Saldivar S.O., Bockholt A.J., Rodney L.W., Knabe D.A., 1988. Nutritional evaluation of tortillas and tortilla chips from quality protein maize. Cereal Food World 33, 233-235 
Steel R.G.D., Torrie J.H., 1980. Principles and Procedures of Statistics: a Biometrical Approach. McGraw-Hill, New York

Subsucan C.P., Olanday P.O., Cambel I.H., 1990. Advantages of QPM in broiler rations. Maize Res. Develop. J. 1, 5-17

Sullivan J.S., Knabe D.A., Bockholt A.J., Gregg E.I., 1989. Nutritive value of quality protein maize and food corn for starter and grower pigs. J. Anim. Sci. 67, 1285-1292

Vasal, S.K., Villegas E., Bjarnason M., Gelaw B., Goertz P., 1980. Genetic modifiers and breeding strategies in developing hard-endosperm opaque-2 material. In: W.G. Pollmer, R.H. Phipps (Editors). Improvement of Quality Traits of Maize for Grain and Silage Use. Martinus Nijhoff, London

Zarkadas C.G., YU Z., Hamilton R.I., Pattison P.L, Rose N.G.W., 1995. Comparison between the protein of northern adapted cultivars of common maize and quality protein maize. J. Agric. Food Chem. 43, 84-93

\section{STRESZCZENIE}

\section{Ocena wartości pokarmowej kukurydzy o zmodyfikowanym bialku jako składnika diety kur-} cząt ras nieśnych

Doświadczenie przeprowadzono w dwóch okresach: wzrostowym i nieśnym na 300 8-tygodniowych rosnących kurkach (Shaver Starcross linia 579). W okresie wzrostu ( $8-18$ tyg. życia) zastosowano 5 izokalorycznych diet: kontrolne, ze zwykłą kukurydzą i mączką rybną zawierające $16 \%$ białka ogólnego (NM1) lub 14\% b.og. (NM2); trzy doświadczalne, w których zwykłą kukurydzę zastappiono kukurydzą o zmodyfikowanym białku, zawicrającc 16, 15 lub 14\% b.og., odpowiednio QPM1, QPM2 lub QPM3. W okresie nieśności skarmiano podobne diety, lecz z niższą zawartością białka ogólnego 15, 13, 15, 14 i 13\%, odpowiednio.

Zastapienie kukurydzy NM przez QPM w dawce o $14 \%$ b.og. (QPM3) nie pogorszyło istotnie wyników produkcyjnych rosnących kurcząt w porównaniu z ptakami otrzymującymi dawkę NM1 o $17 \%$ b.og., natomiast podawanie dawki NM2 spowodowało istotne $(\mathrm{P}<0,05)$ obniżenie przyrostów i wykorzystania paszy. W okresie nieśności skarmianie dawek QPM3 i NM2 (13\% b.og.) spowodowało pogorszenie wyników produkcyjnych kurek.

Otrzymane wyniki wskazuja, że zawartość białka ogólnego w dietach dla niosek może być obniżona do 14\% przy zastąpieniu zwykłej kukurydzy kukurydzą o zmodyfikowanym białku.

QPM - jest pochodną kukurydzy Opaque-2, wychodowanej w Meksyku. 